Full length article

\title{
OPTIMIZATION OF THE CROPPING PATTERN IN CENTRAL YASIN DISTRICT GHIZER, GILGIT-BALTISTAN
}

F. Haq ${ }^{1 *}$, E. Alil, S. Hussain ${ }^{1}$

1 Department of Mathematical Sciences, Karakoram International University Gilgit-Baltistan, Gilgit, 15100, Pakistan

\begin{abstract}
In this research study Linear Programming (LP) Model is applied to determine the maximum profit from the three major crops (wheat, maize and alfalfa) in Central Yasin District Ghizer, where agriculture is the main source of income, however, due to population growth the agricultural land is used to construct buildings, which has minimized the land for agricultural use. In such a challenging condition a method to suggest the cultivation of a maximum profitable crop is the need of time. Therefore, LP model is an appropriate method to decide the profitable crop and to maximize the profit. The study was conducted employing quantitative method of research, with the purpose to compare the maximum profit per annum from the major crops, and to determine the beneficial crop among the three major crops in Central Yasin. All the farmers of the study area who grow the crops were the target population of the study and samples from the target population were selected using random sampling technique. Data was collected by conducting survey in the study area, where selfmade questionnaires were distributed among the samples individually and responses were noted on the spot. The raw data is organized and analyzed using Microsoft Excel for LP model formulation. The result showed that the average land used for the cultivation of wheat, maize and alfalfa in the study area is 0.924 acres, 0.664 acres and 0.75 acres respectively. Furthermore, results of the LP model showed that alfalfa is the optimal solution rather than wheat and maize, and it (alfalfa) gives an average annual net profit of Rs.195634.488.
\end{abstract}

KEYWORDS: Linear Programming; Simplex Method; Optimal Solution; Cropping Pattern.

\footnotetext{
*Corresponding author (email: fazal.haq@kiu.edu.pk)
} 


\section{INTRODUCTION}

Linear Programming (LP), is a sub-field of Optimization theory, which itself is a subfield of applied mathematics, is a class of mathematical problems, in which a linear function is maximized (or minimized), subject to given linear constraints (Nakhanu, Toili, \& Nyongesa, 2015). Here the word programming is a synonym for planning not a computer programming like Java, C++ or other basic computer programming. Linear programming is generalization of linear algebra. Linear programming method finds the best solution to the real world problems if the problem is represented by mathematical equalities or inequalities. Linear programming (LP) or Linear Optimization (LO) is an operations research technique which is widely used in finding solutions to complex managerial decision problems (Ezema \& Amakom, 2012). All linear programming problems have the objective to maximize the profit or minimize the cost.

Furthermore, linear programing with simplex procedure is an appropriate method to optimize land allocation for rice, wheat, pulses and other crops, (Sofi et al., 2015). In the same way, Aparnathi and Bhatt (2014) formulated linear programming model for optimal cropping pattern for economic benefits of Mrbc Command Area in which surface and ground water were considered as decision variables. The findings of their study showed that linear programming technique is convenient method for obtaining optimal results. Felix et al. (2013) used linear programming model to work out optimal crop combination between maize, soya beans and cotton crops for a rural farmer in Zimbabwe. They compared their results with farmer plans, and the result showed that LP model produced an optimal crop combination that gives higher income where the income difference was $72.29 \%$.

Furthermore, Majeke (2013) addressed on the resource allocation problem in Marondera, Zimbabwe with the help of linear programming procedure. The crops considered were tobacco, maize, soya beans and potatoes. Model result suggested that tobacco and potato crops were part of the optimal solution which gained acreage by $128 \%$ and $38 \%$ respectively whereas maize and soya beans were not part of the optimal solution. The LP result was compared with traditional method of planning and proved that LP model is most superior. The income difference was $35 \%$.

In the same way, Ezema and Amakom (2012) applied linear programming method in Golden Plastic Industry Limited, Enugu, Nigeria to optimize profit from the different sizes of pipe production. The result suggested producing only two sizes of the total eight "PVC" pipes. The industry should produce $114,317.2$ pieces of $25 \mathrm{~mm}$ by $4.5 \mathrm{~m}$ conduit pipes and $7,136.564$ pieces of $20 \mathrm{~mm}$ by $5.4 \mathrm{~m}$ 
thick pressure pipes per month, to obtain a maximum profit of $\mathrm{N} 1,964,537$.

Likewise, Afridi, Ishtiaq, and Ahmad (2009) applied linear programming model to allocate optimal land allocation for strawberry production in a sub-tropical areas; Jandai and Sarkai of NWFP. Wheat and sugarcane were considered as a comparative crop. Their findings were: (1) Strawberry was cropped on 0.91 acres, wheat on 1.70 acres and sugarcane on 0.91 acres. (2) The gross revenue per acre was estimated at Rs.154751, Rs.16094 and Rs.39059 for strawberry, wheat and sugar cane respectively. (3) The LP model results suggested that strawberry should be cropped on 0.68 acres and sugarcane on 2.8 acres to realize the maximum net revenue of Rs. 161263 but wheat was not included in the optimal solution.

Moreover, Khan et al. (2005) conducted a research study on 4652 thousand acres of the irrigated area in three districts of Bahawalpur, Punjab where the crops supposed under the study were wheat, maize, basmati rice, IRRI rice, cotton and sugarcane. The LP model recommended cultivating the cotton crop which gained acreage by about $10 \%$ and the overall optimal crop acreage decreased by $1.76 \%$. LP result also showed that the optimal income was increased by $3.38 \%$. Similarly, Hassan et al. (2005) collected primary data from four districts of Dera Ghazi Khan Division of Punjab province by conducting a case study on 3913 thousand acres of the irrigated area, to determine the optimal cropping pattern, production and income level. Linear programming method was considered as a suitable tool for this study and they took five major crops under consideration i.e. wheat, cotton, sugarcane, basmati rice and IRRI rice. The result of the LP model showed that cotton was the only crop which gained acreage by $10 \%$ at the expense of all other crops. The result also showed that overall optimal crop acreage decreased by $1.64 \%$ and the income increased by $2.91 \%$.

In the same way, Hassan et al. (2004) designed linear programming model to optimize cropping pattern in Faisalabad Division, on wheat, basmati rice, IRRI rice, cotton, sugarcane, maize and potato. The results of the LP procedure showed that wheat, cotton and maize gained acreage by $5-10 \%$. This result also showed that basmati rice, IRRC rice, sugarcane and potato are the main losers. Overall optimal crop acreage increased by $1.88 \%$ and optimal income was increased by around $2 \%$. Singh et al (2001) cited by Hassan (2004), found that different water availability levels by applying LP model to suggests the optimal cropping patterns in the command of Shahi Distributary in Uttar Pardesh, India.

It is a common observation and practice that farmers in the study area grow crops, using the traditional ways and past experiences rather than experimental results or modern means. As a result of which monitoring and 
Haq et al., J. mt. area res. 05 (2020) 10-18

evaluation of the profit and loss in terms of investment and profit earning remains a problem. Therefore, the present study was conducted to compare the maximum profit per annum from the major crops, and to explore the beneficial crop among the three major crops (wheat, maize and alfalfa) in the study area, using linear programming method.

\section{OBJECTIVES}

The objective of current study is to develop a LP model to maximize the net profit gained from three major crops wheat, alfalfa and potato in Central Yasin District Ghizer

\section{STUDY AREA}

Yasin valley of Gilgit-Baltistan is located at a distance of $137 \mathrm{~km}$ from central Gilgit, and at a distance of $62 \mathrm{~km}$ from the Headquarter namely the Gahkuch, of district Ghizer. The current population of the area is approximately 90,000 (Gulistan, 2015). The present study was conducted in two of the villages of Yasin, namely, Manich and Noh. The area was selected because of three main reasons. Firstly, people of this area are associated with farming and they grow wheat, maize and alfalfa as source of both human and animal food and source of cash earning respectively. Secondly, it was easily accessible because this area is the researcher's home town therefore, it was cost effective for the collection of data, and thirdly, the time was limited.

\section{MAJOR CROPS OF THE STUDY AREA}

Agriculture is the main source of income of the study area where wheat, maize and alfalfa crops are grown mostly. In addition to these crops; barley and vegetables are also grown. The vegetables grown are potatoes, tomatoes, onion, carrot and sonachal (Malva Verticillata), and so on. In the study area only irrigated agriculture and crops' growing is possible. Glaciers and seasonal snow deposits are the only source water reservoirs. The agricultural lands are prepared by using machinery (tractors). Generally, farming is the profession of male in the study area and farming the occupation of almost $90 \%$ of the people. Among the three major crops alfalfa is the only one which is a double harvesting crop.

\subsection{Wheat. Wheat is grown as primary food} crop in the study area, where the land owners (farmers) allocate major part of their land for the cultivation of wheat crop. The cultivation of wheat starts in the month of April while the harvesting starts in the month of August. The flour of wheat is used to prepare bread, which is the basic food of the local people and the fodder is used as animal's food.

4.2 Maize. Maize is the second major crop after wheat. Generally, maize is sown in the month of May and harvested in October. Similarly, the flour of maize is used to prepare bread, which is the basic food of the local 
people and the fodder is used as animal's food.

\subsection{Alfalfa (Medicago Sativa)}

It is an animal food source crop grown in the study area however; in the early juvenile stage some people use it as human food (vegetable) too. It is also grown as a cash crop in the study area. Alfalfa is the only crop in the study area which is harvested two times per year.

\section{DATA AND METHOD OF SOLUTION}

This comparative study is conducted in quantitative paradigm; random sampling technique is used for the selection of samples, because random sampling ensures equal chance for each individual to be counted in the samples. First we used stratified sampling in which there were three major groups of farmers; the wheat growers, maize growers and the alfalfa growers, followed by simple random sampling to collect the data from the three types of farmers. Randomly 300 farmers (100 for each crop) as sample were selected for this study.

\section{LP MODEL FORMULATION}

Formulation is the process of translating real world problem into a linear program. To formulate LPM mathematically, four major steps were used as shown in figure 1.

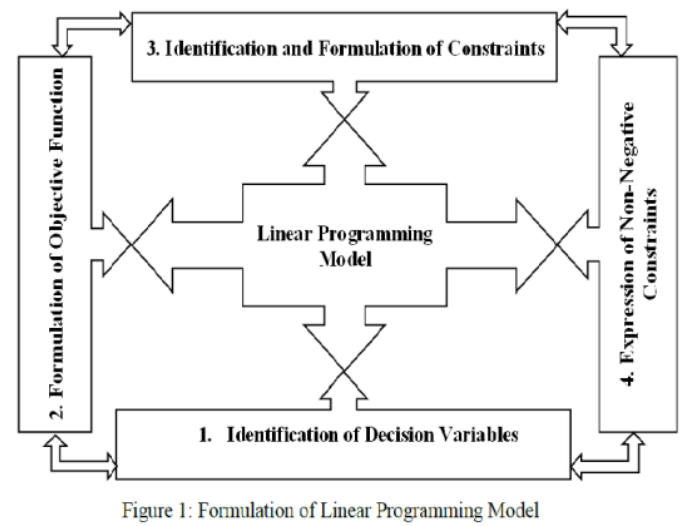

Table 1 show that an average of 26 days are spent by per person and an average of 28 fertilizer bags are used to grow wheat crop in the study area, in one season. Similarly, an average of 26 days is spent by per person and an average of 25 fertilizer bags are used to grow maize crop in the study area, in one season. For the alfalfa crop cultivation, the total person days were calculated to be 36 and 32 bags of fertilizer were used by the alfalfa growers.

The output data were used to formulate linear programming model and carried out this model to find optimal land allocation. The standard LP model for the present study using this calculated data is modeled as following; 


$$
\begin{array}{ll}
25 x_{1}+26 x_{2}+36 x_{3} \leq 87 & \text { (Labour Constraint) } \\
28 x_{1}+25 x_{2}+32 x_{3} \leq 85 & \text { (Fertilizer Constraint) } \\
33840 \mathrm{x}_{1}+23517 \mathrm{x}_{2}+31084 \mathrm{x}_{3} \leq 88441 & \text { (Capital Constraint) } \\
x_{1}+x_{2}+x_{3} \leq 2.338 & \text { (Land Allocation) } \\
x_{1}, \quad x_{2}, \quad x_{3} \geq 0 & \text { (Non-Negativity Constraint) }
\end{array}
$$

\begin{tabular}{|c|c|c|c|c|c|}
\hline \multicolumn{2}{|c|}{ Activities } & Wheat & Potato & Alfalfa & \\
\hline \multicolumn{2}{|c|}{ Objective Function } & $33,375.43$ & $30,423.545$ & $83,676.99$ & Maximize \\
\hline $\begin{array}{c}\text { Resources } \\
\text { Labor } \\
\text { Fertilizer } \\
\text { Capital }\end{array}$ & $\begin{array}{c}\text { Units } \\
\text { Person } \\
\text { days } \\
\text { Kg } \\
\text { Rupees }\end{array}$ & $\begin{array}{c}25 \\
28 \\
33,839.57\end{array}$ & $\begin{array}{c}26 \\
25 \\
23,516.455\end{array}$ & $\begin{array}{c}36 \\
32 \\
31,084.01\end{array}$ & $\begin{array}{c}\text { Available } \\
\leq 87 \\
\leq 85 \\
\leq 88,441\end{array}$ \\
\hline Land & Acres & 1 & 1 & 1 & $\leq \mathbf{2 . 3 3 8}$ \\
\hline
\end{tabular}

Where,

$x_{1}=$ indicates the land allocation in acre for the growth of wheat.

$x_{2}=$ indicates the land allocation in acre for the growth of maize.

$x_{3}=$ indicates the land allocation in acre for the growth of alfalfa.

Table 1: Linear Programming matrix

\section{COMPARISON OF RESULTS}

Simplex method is used to solve the obtained mathematical model. The optimal result obtained for allocation of land from the LP model is displayed in table 2. The LP results are compared with the farmer's decision is presented in Table 3. LP results indicates that both wheat and maize are not the part of optimal solution. The overall findings of the study revealed that alfalfa is the most profitable crop as compared to the other two major crops namely, wheat and maize. Furthermore, the findings of the study showed that the cultivation of alfalfa in 2.338 acres of land maximizes the net profit up to Rs. 195634.488 per season/year.
Table 2: Optimal Land Allocation Suggested by LP Model

\begin{tabular}{|l|l|l|l|}
\hline & $\begin{array}{l}x_{1}= \\
\text { Wheat } \\
\text { (acres) }\end{array}$ & $\begin{array}{l}x_{2}= \\
\text { Maize } \\
\text { (acres) }\end{array}$ & $\begin{array}{l}x_{3} \\
\text { Alfalfa } \\
\text { (acres) }\end{array}$ \\
\hline Production & 0 & 0 & 2.338 \\
\hline $\begin{array}{l}\text { P=Net } \\
\text { Profit }\end{array}$ & \multicolumn{2}{|c|}{ RS. 195634.488 } \\
\hline
\end{tabular}


Table 3: Comparison of Land allocation under LP solution with farmer's plan

\begin{tabular}{|l|l|l|l|}
\hline $\begin{array}{l}\text { Crop } \\
\mathbf{s}\end{array}$ & $\begin{array}{l}\text { Farmers } \\
\text { Plan(Acr } \\
\text { es) }\end{array}$ & $\begin{array}{l}\text { Optima } \\
\text { l } \\
\text { Solutio } \\
\mathbf{n} \\
\text { (Acres) } \\
\text { Plan }\end{array}$ & $\begin{array}{l}\text { Percenta } \\
\text { ge of } \\
\text { Farmers }\end{array}$ \\
\hline $\begin{array}{l}\text { Whe } \\
\text { at } \\
\text { Potat } \\
\text { O } \\
\text { Alfalf }\end{array}$ & 0.924 & 0.0 & 0.366 \\
$\begin{array}{l}\text { a } \\
\text { Total }\end{array}$ & $\begin{array}{l}0.75 \\
\mathbf{1 4 7 , 4 7 5 . 9}\end{array}$ & $\begin{array}{l}\mathbf{1 9 5 , 6 3 4} \\
\mathbf{6 5}\end{array}$ & $\mathbf{3 4 8 . 6 3}$ \\
\hline
\end{tabular}

\section{RECOMMENDATIONS}

Based on the findings of the present study the following recommendations as way forward are made;

- Alfalfa is a profitable crop which is a source of cash earning and income generation, therefore, it needs to be grown at maximum level in the study area.

- The farmers of the study area needs to be given free of interest loans or subsidy by the government especially the agricultural sector to manage fertilizers and seeds of alfalfa.

- Farmers need to be trained by the government (Agriculture department), by conducting trainings and sessions to maximize the cultivation of alfalfa.

\section{REFERENCES}

1. Abdulai, A, Resource Use Efficiency in Vegetable Production: The Case of Smallholder Farmers in the Kumasi Metropolis. A Published Master Thesis University of Sciences and Technology, Department of Agricultural Economics, Agribusiness and Extension, (2006, August). 1-107.

2. Afridi, G. S., Ishtiaq, M., \& Ahmad, S, Cost and Revenue Analysis of Strawberry Production in the Sub-Tropical Areas of NWFP, Pakistan. Pakistan Journal of Life and Social Sciences, (2009). 7(1), 59-65.

3. Aparnathi, M. G., \& Bhatt, P. K, Linear Programming for Optimal Cropping Pattern for Economic Benefits of Mrbc Command Area. International Journal for Innovative Research in Science and Technology, (2014, June). 1(1), 47-54, ISSN: $2349-6010$

4. Ezema, B. I., \& Amakom, U, Optimizing Profit with the Linear Programming Model: A Focus on Golden Plastic Industry Limited, Enugu, Nigeria. Interdisciplinary Journal of Research in Business, (2012) . 2(2), 37-49,

5. Felix, M., Judith, M., Jonathan, M., \& Munashe, S., Modelling a Small Farm Livelihood System Using Linear Programming in Bindura, Zimbabwe. Research Journal of Management Sciences, (2013), 2(5), 20-23, ISSN: 23191171, www.isca.in. 
6. Gulfam, Application of Linear Programming to Maximize Profit of Potato Production in Central Hunza. An Unpublished BS Thesis, Karakoram International University Gilgit, (2015). 1-35.

7. Gulistan, Application of Linear Programming to Maximize the Profit of Potato Production in Central Yasin. An Unpublished BS Thesis, Karakoram International University Gilgit, (2015), 1-27.

8. Hassan, I. Use of Linear Programming Model to Determine the Optimum Cropping Patterns for the Irrigated Punjab with National and WTO Price Options. A Published Doctor of Philosophy Thesis in Farm Management, University of Agriculture,Faisalabad, (2004), 1-248.

9. Hassan, I., Raza, M. A., Khalil, M., \& Ilahi, $R$, Determination of Optimal Cropping Pattern in Faisalabad Division (Pakistan). International Journal of Agriculture and Biology, (2004), 06(5), 901-903.

10. Hassan, I., Raza, M. A., Khan, I. A., \& Ilahi, $R$, Use of Linear Programming Model to Determine the Optimal Cropping Pattern, Production and Income Level: A Case Study from Dera Ghazi Khan Division. Journal of Agriculture and Social Sciences, (2005), 1(1), 32-34 www.ijabjass.org.

11. Hira, Operations Research (first ed.). S. Chand and Company Ltd, (2012), 7361, Ram Nagar, New Delhi-110055.
12. Ikechi, K. S., A, O. B., \& C, E. I, Application of Linear Programming Techniques to Decision Making. Mathematical Theory and Modeling, (2014), 1, 100-111 ISSN: 2224-5804 (Paper), ISSN: 2225-0522 (Online).

13. Khan, I. A., Khan, M. A., Hassan, I., Cheema, N., \& Maryam, R, Use of Linear Programming to Determine Optimum Cropping Pattern in Bahawalpur, Panjab, Pakistan. Pakistan Journal of Life and Social Sciences, (2005), 3(1-2), 21-23.

14. Majeke, F, Optimum Combination of Crop Farm Enterprices: A Case Study of a Small-Scale Farm in Marondera, Zimbabwe. The International Researcher Journal "International Researchers", (2013, march), 2(1), 60-65.

15. Majeke, F., Mubvuma, M. T., Makaza, K., \& Mutambara, J, Optimum Combination of Crop Farm Activities: Application of Linear Programming Model to a Rural Farmer in Zimbabwe. Greener Journal of Econmics and Accounting, (2013, June), 2(2), 058-061, ISSN: 2354-2357.

16. Nakhanu, S. B., Toili, W. W., \& Nyongesa, K, Application of Linear Programming Knowledge and Skills to Real Life Contexts by Secondary School Students in Kenya. Journal of Scientific Research and Reports, (2015), 8(1), 1-7, ISSN: 2320-0227,

17. Newman, A. M., \& Weiss, M, A Survey of Linear and Mixed-Integer Optimization Tutorials. Transaction on Education, 
(2013, September), 14, 26-38, ISSN: 15320545 (Online).

18. Philip, G. E., Murray, W., \& Saunders, M. A, George B. Dantzig and Systems Optimization. To Appear in Discrete Optimization, (2007, January), 1-11.

19. Rajeiyan, $K$. et al, Using Linear Programming in Solving the Problem of Services Company's Costs. Singaporean Journal of Business Economics and Management Studies, (2013), 1, 68-73.

20. Sofi, N. A., Ahmed, A., Ahmad, M., \& Bhat, B. A, Decision Making in Agriculture: Linear Programming Approach. International Journal of Modern Mathematical Sciences, (2015), 13(2), 169-169, ISSN: 2166-286.

21. Todd, M. J, The Many Facets of Linear Programming. maths program, Digital Object Identifier, (2001).

22. Veiga, G, A Brief History of Computational Linear Programming. 1st Brazelian Workshop on Interior Point Method, (2015, April 27-28).

Received: 25 January 2020. Revised/Accepted: 13 March 2020. 